\title{
PENGEMBANGAN KAPASITAS KELEMBAGAAN (CAPACITY BUILDING) \\ DALAM UPAYA MENINGKATKAN KINERJA PEGAWAI (STUDI PADA KANTOR PELAYANAN PERBENDAHARAAN NEGARA/KPPN KUDUS)
}

\author{
Asih Widi Lestari; Dhika Bagus Wicaksono \\ Program Studi Administrasi Publik, FISIP, Universitas Tribhuwana Tunggadewi \\ Email: lestariwidi263@gmail.com
}

\begin{abstract}
The purpose of this research is to describe and analyze capacity building in order to improve the employee performance at KPPN Kudus Regency, The restrictingfactors ofcapacity building in order to improve the employee performance at KPPN Kudus Regency.This research uses descriptive research methods with qualitative approaches. The result of research iscapacity building in order to improve employee performance in KPPN Kudus is strong through leadership that done by the head of KPPN Kudus, the program increased discipline that is just right from the Ministry of Finance in improving discipline employees through the giving of reward and punishmen, and facilities that are in KPPN Kudus that was already complete and comfortable.The restricting factors of capacity building in order to improve the employee performance at KPPN Kudus Regency is the existence of some employees who don't know the development of rules and some employees were not disciplined.
\end{abstract}

Keywords: Development; Institutional Capacity; Employee Performance

Abstrak: Tujuan dari penelitian ini adalah untuk mendiskripsikan dan menganalisis Pengembangan Kapasitas (Capacity Building) Kelembagaan dalam Upaya Meningkatkan Kinerja Pegawai di Kantor Pelayanan Perbendaharaan Negara/KPPN Kabupaten Kudus, Faktor penghambat Pengembangan Kapasitas (Capacity Building) Kelembagaan dalam Upaya Meningkatkan Kinerja Pegawai di Kantor Pelayanan Perbendaharaan Negara/KPPN Kabupaten Kudus. Penelitian ini menggunakan metode penelitian deskriptif dengan pendekatan kualitatif. Hasil dari penelitian adalah upaya pengembangan kapasitas kelembagaan (capacity building) dalam meningkatkan kinerja pegawai di Kantor Pelayanan Perbendaharaan Negara/KPPN Kabupaten Kudus dirasa sudah baik melalui kepemimpinan yang dilakukan oleh Kepala KPPN Kudus, program peningkatan kedisiplinan yang sudah tepat dari Kementerian Keuangan dalam meningkatkan kedisiplinan pegawai melalui pemberian reward dan punishment, dan fasilitas yang ada di KPPN Kudus yang sudah lengkap dan nyaman. Adapun faktor penghambat pengembangan kapasitas kelembagaan (capacity building) dalam upaya meningkatkan kinerja pegawai di Kantor Pelayanan Perbendaharaan Negara/KPPN Kabupaten Kudus adalah adanya beberapa pegawai yang tidak mengetahui perkembangan aturan dan beberapa pegawai tidak disiplin.

Kata Kunci: Pengembangan; Kapasitas Kelembagaan; Kinerja Pegawai 


\section{PENDAHULUAN}

Dalam upaya mewujudkan tujuan nasional tersebut, dibutuhkan sebuah penyelenggaraan pemerintahan yang baik sehingga dapat melaksanakan pembangunan sesuai dengan tujuan yang telah ditetapkan. Di dalam penyelenggaraan pemerintahan ini, tentunya membutuhkan pegawai negeri sipil yang memiliki tingkat kesadaran tinggi akan kewajibannya dalam menjadi aparatur negara yang berfungsi sebagai abdi negara dan abdi masyarakat. Hal ini sesuai dengan pendapat Nainggolan (1987:23), yang mengatakan "Kelancaran pelaksanaan pemerintahan dan pembangunan nasional terutama tergantung dari baik dan idealnya aparatur Negara, kesempurnaan aparatur negara pada pokoknya tergantung dari baik dan idealnya pegawai negeri'. Berdasarkan pendapat ini, diketahui bahwa sebuah keberhasilan dari pembangunan bangsa dipengaruhi oleh kesempurnaan dari aparaturnya baik kesempurnaan sikap, mental, maupun akhlak. Menurut Marsono (1974:66), Pegawai Negeri yang baik dan ideal adalah Pegawai Negeri yang setia dan patuh pada Pancasila, Undang-Undang Dasar 1945 dan pemerintah serta bersatu padu, bermental mulia, mempunyai kedisiplinan yang tinggi, mempunyai wibawa yang tinggi, berdaya guna, berkualitas baik dan mempunyai kesadaran yang tinggi akan tanggung jawab sebagai aparatur negara.

Melihat kenyataan kondisi aparatur di Indonesia, menurut Sulistiyani (2004:329) ada beberapa masalah yang dihadapi oleh Pemerintah Indonesia terkait dengan Sumber Daya Manusia (SDM). SDM tersebut adalah Pegawai Negeri Sipil (PNS) yang bekerja dan mengabdi di lingkungan birokrasi untuk melaksanakan tugas pokok dan fungsi sesuai yang telah ditetapkan. Permasalahan tersebut antara lain terus meningkatnya jumlah PNS (Pegawai Negeri Sipil) dari tahun ke tahun, rendahnya kualitas dan ketidaksesuaian kemampuan yang dimiliki, kesalahan penempatan, serta tidak jelasnya jalur karier yang ditempuh. Dari pendapat tersebut, maka dapat diketahui bahwa kualitas dari pegawai negeri sipil di Indonesia dapat dikatakan rendah.

Gambaran tentang rendahnya kualitas dari pegawai negeri sipil di Indonesia telah mendapat sorotan yang tajam, antara lain rendahnya profesionalisme pegawai, budaya kerja serta etos kerja yang masih sangat rendah, dan tentunya penerapan peraturan disiplin yang tidak dilaksanakan secara konsisten. Persoalan klasik seperti ini merupakan persoalan yang umum ditemukan sejak dahulu sampai sekarang dan merupakan fenomena yang tidak asing lagi bagi masyarakat. Hal ini sesuai dengan hasil penelitian dari Effendy (2005:36) berpendapat bahwa kualitas dari sumber daya khususnya SDM dan profil PNS masih rendahnya, kemampuan dan mental PNS (Pegawai Negeri Sipil) adalah suatu manajemen PNS yang masih kurang, mulai dari awal perencanaan kebutuhan akan PNS sampai pada pemberhentian. Permasalahan-permasalahan tersebut hampir tidak pernah terurai secara tuntas sehingga akibatnya, kinerja dan profesionalisme pegawai negeri sipil selalu menjadi sorotan banyak pihak. Kemudian hal ini diperkuat dengan pernyataan dari mantan Menteri Negara Pendayagunaan Aparatur Negara (Menneg PAN) Taufiq Effendi yang mengatakan bahwa terdapat 55 persen dari total pegawai negeri sipil yang mencapai sekitar 3,6 juta orang berkinerja buruk. Para pekerja ini hanya mengambil gajinya tanpa berkontribusi berarti terhadap pekerjaannya (Kompas, 12 Januari 2007).

Tujuan dari penelitian ini adalah untukmendeskripsikan dan menganalisis Pengembangan Kapasitas Kelembagaan (Capacity Building) dalam Upaya Meningkatkan Kinerja Pegawai di Kantor Pelayanan Perbendaharaan Negara/ KPPN Kabupaten Kudus; untuk mendeskripsikan dan menganalisis faktor penghambat Pengembangan Kapasitas 
REFORMASI

ISSN 2088-7469 (Paper) ISSN 2407-6864 (Online)

Volume 9 Nomor 1 (2019)

Kelembagaan (Capacity Building) dalam Upaya Meningkatkan Kinerja Pegawai di Kantor Pelayanan Perbendaharaan Negara/ KPPN Kabupaten Kudus.

\section{TINJAUAN PUSTAKA}

\section{A. Pengembangan Kapasitas (Capacity Building)}

Menurut Merilee S.Grindle (1997:6-22), Capacity Building adalah "Capacity building is intended to encompass a variety of strategies that have to do with increasing the efficiency, effectiveness, and responsiveness of government performance."

\section{B. Pembangunan Lembaga (Institutional Building)}

Milton J. Esman didefinisikan sebagai perencanaan, penataan dan bimbingan untuk organisasi-organisasi baru atau yang disusun kembali untuk: (1) Menghasilkan suatu perubahan dalam nilai, fungsi, teknologi baik dari fisik maupun sosial; (2) Mewujudkan, mengembangkan dan membentuk hubungan normatif melalui tindakan yang baru; (3) Mengembangkan jejaring atau kaitan-kaitan (linkages) dalam upaya mendapatkan dukungan dan kelengkapan dari lingkungannya. Sedang terciptanya kelembagaan (institutionally) adalah kondisi akhir yang diharapkan, atau sebagai variable evaluatif untuk menilai keberhasilan pengembangan kelembagaan.

\section{Administrasi Kepegawaian Negara}

Menurut Felix A.Nigro dalam bukunya Public Personnel Administration (dalam Moekijat, 1991:2) mendefinisikan administrasi kepegawaian negara ialah "Personnel Administration is the art of selecting new employees and making use of old ones in such manner that the maximum quality and quantity of output and service are obtained from the working force". Dan di dalam administrasi kepegawaian negara terdapat kegiatan-kegiatan di dalamnya. Menurut Moekijat dalam bukunya yang berjudul "Administrasi Kepegawaian Negara", ada 9 (Sembilan) kegiatan dalam Administrasi Kepegawaian, yang meliputi: Perencanaan Pegawai; Analisis Jabatan dan Analisis Beban Kerja; Penarikan Tenaga Kerja, Seleksi dan Penempatan; Orientasi; Pelatihan; Penilaian Pelaksanaan Pekerjaan; Perencanaan Karier; Kompensasi; Promosi dan Pemindahan.

\section{Kinerja}

Menurut Moeheriono (2014:95), pengertian kinerja atau performance adalah sebuah gambaran tentang pencapaian atas implementasi sebuah program kegiatan dalam upaya mewujudkan sasaran, tujuan, visi dan misi organisasi yang telah disebutkan melalui perencanaan strategis sebuah organisasi. Kinerja dapat dilihat dan diukur jika individu atau sekelompok pegawai telah memiliki kriteria dan standar kesuksesan tolak ukur yang ditetapkan oleh organisasi. Oleh karena itu, jika tanpa tujuan dan target yang ditetapkan dalam pengukuran, maka kinerja pada seseorang atau kinerja organisasi tidak mungkin dapat diketahui bila tidak ada tolak ukur keberhasilannya.

\section{METODE PENELITIAN}

Penelitian ini menggunakan metode penelitian deskriptif dengan pendekatan kualitatif.Sumber data yang digunakan adalah data primer dan data sekunder.Teknik pengumpulan data dengan observasi, wawancara dan dokumentasi.Instrumen penelitian yang digunakan yaitu peneliti sendiri, pedoman wawancara, dan catatan lapangan. Metode analisis 


\section{REFORMASI}

ISSN 2088-7469 (Paper) ISSN 2407-6864 (Online)

Volume 9 Nomor 1 (2019)

data yang digunakan adalah Analisis Model Interaktif oleh Miles dan Huberman (1992:20) yaitu dengan cara pengumpulan data, reduksi data, penyajian data, dan penarikan kesimpulan. Pada penelitian ini yang menjadi lokasi penelitian adalah Kabupaten Kudus, sedangkan situs penelitian adalah Kantor Pelayanan Perbendaharaan Negara/ KPPN Kudus.

\section{HASIL DAN PEMBAHASAN}

Pengembangan Kapasitas Kelembagaan (Capacity Building) dalam Upaya Meningkatkan Kinerja Pegawai di Kantor Pelayanan Perbendaharaan Negara/KPPN Kabupaten Kudus

1. Kepemimpinan;

Kepemimpinan merupakan proses dalam mempengaruhi, memotivasi, dan membuat orang lain untuk berkontribusi terhadap kesuksesan dan efektivitas suatu organisasi dalam mencapai tujuan-tujuannya. Baik buruknya pemimpin juga berpengaruh terhadap pengembangan kapasitas dalam sebuah organisasi/ lembaga. Kepemimpinan yang dilakukan oleh Kepala KPPN Kudus sudah baik dalam meningkatkan kinerja pegawainya.

a. Program

Upaya peningkatan kinerja pegawai sudah dilakukan dari pusat yaitu Kementerian Keuangan, yaitu pelaksanaan sistem reward dan punishment kepada seluruh pegawai Kementerian Keuangan. Dengan hal yang demikian, ternyata memberi dampak yang bai dalam kedisiplinan pegawai di Kementerian Keuangan.

b. Sumber Daya (Fasilitas)

Fasilitas yang ada di KPPN Kudus dirasa sudah lengkap dan nyaman. Suasana dan kondisi inilah yang membuat para pegawai KPPN Kudus betah berada di kantor dan disiplin dalam bekerja. Berdasarkan hasil observasi peneliti, seluruh ruangan di KPPN Kudus sangat bersih, berAC, tertata rapi, dan memiliki fasilitas yang lengkap.

Faktor Penghambat dalam Pengembangan Kapasitas Kelembagaan (Capacity Building) dalam Upaya Meningkatkan Kinerja Pegawai di Kantor Pelayanan Perbendaharaan Negara/ KPPN Kudus

Sebuah pengembangan kapasitas kelembagaan, tidak akan pernah terlepas dari faktor penghambat. Dan yang menjadi faktor penghambat dalam pengembangan kapasitas kelembagaan di KPPN Kudus adalah:

a. Beberapa Pegawai yang Tidak Mengetahui Perkembangan Aturan.

Penyelenggaraan sebuah pemerintahan tidak selamanya berjalan statis. Namun berjalan dinamis sesuai dengan kebutuhan masyarakat yang semakin bertambah.Begitu juga dengan aturan-aturan yang berlaku dalam sebuah pemerintahan, termasuk juga aturan dalam Kementerian Keuangan. Aturan-aturan tersebut tentunya tiap waktu akan berubah karena disesuaikan dengan aturan pemerintah pusat. Namun kendala yang sering dihadapi adalah beberapa pegawai ini tidak mengetahui mengenai perubahan perkembangan aturan ini.Hal ini disebabkan oleh sikap apatis dari pegawai KPPN Kudus itu yang tidak mau tahu mengenai perkembangan aturan tersebut.Sehingga administrasi yang dilaksanakan lebih cenderung menggunakan system yang biasa mereka jalani selama turun temurun.

b. Beberapa pegawai tidak disiplin

Disiplin adalah sikap mental yang tercermin dalam pembuatan tingkah laku seseorang atau masyarakat berupa kepatuhan atau ketaatan terhadap peraturan yang diterapkan dengan baik oleh pemerintah.Disiplin sangat berkaitan erat dengan kinerja suatu organisasi, tidak 


\section{REFORMASI}

ISSN 2088-7469 (Paper) ISSN 2407-6864 (Online)

Volume 9 Nomor 1 (2019)

terkecuali dengan organisasi pemerintah. Kedisiplinan para pegawai dalam bekerja akan sangat membantu pada kesuksesan pelaksanaan pekerjaan itu sendiri. Seudah bukan rahasia lagi kalau selama ini kedisiplinan para pegawai pemerintah dalam bekerja masih kurang baik. Salah satu bukti yang paling mudah dilihat adalah seringnya para pegawai instansi pemerintah yang terlambat datang ke kantor atau pulang dari kantor sebelum waktunya. Hal ini menunjukkan bahwa pelaksanaan disiplin waktu masih sangat buruk.

Disiplin waktu memang merupakan jenis disiplin yang paling mudah dilihat dan di control baik oleh manajemen yang bersangkutan maupun oleh masyarakat. Gambaran umum oleh masyarakat terhadap ada atau tidaknya disiplin memang di cerminkan oleh kedisiplinan dalam jam kerja (disiplin waktu). Tidak adanya disiplin waktu yang baik dari para pegawai seringkali menghambat kinerja aparat pemerintah dalam menjalankan tugas-tugasnya utamanya.

\section{KESIMPULAN}

1. Upaya pengembangan kapasitas kelembagaan (capacity building) dalam meningkatkan kinerja pegawai di Kantor Pelayanan Perbendaharaan Negara/ KPPN Kabupaten Kudus dirasa sudah baik melalui kepemimpinan yang dilakukan oleh Kepala KPPN Kudus yang sudah baik dalam meningkatkan kinerja pegawainya, program peningkatan kedisiplinan yang sudah tepat dari Kementerian Keuangan dalam meningkatkan kedisiplinan pegawai melalui pemberian reward dan punishment, dan fasilitas yang ada di KPPN Kudus yang sudah lengkap dan nyaman.'

2. Adapun faktor penghambat pengembangan kapasitas kelembagaan (capacity building) dalam upaya meningkatkan kinerja pegawai di Kantor Pelayanan Perbendaharaan Negara/ KPPN Kabupaten Kudus adalah adanya beberapa pegawai yang tidak mengetahui perkembangan aturan dan beberapa pegawai tidak disiplin.

\section{DAFTAR PUSTAKA}

Solichin, Abdul Wahab. 2008. Analisis Kebijaksanaan : Dari Formulasi ke Implementasi Kebijaksanaan Negara. Edisi 2. Jakarta: Bumi Aksara.

Anderson. 1979. Public Policy Making. New York : Hol, Rine and Winston.

Anonymous. 2011. Pematangan Evaluasi Reformasi Birokrasi: Pencabutan Hingga Pengurangan Tunjangan Remunerasi. Diakses tanggal 14 Mei 2012 dari <http://www.jpnn.com/read/2011/03/24/87656/Pencabutan-Hingga-PenguranganTunjangan-Remunerasi->

Direktorat Aparatur Negara, 2010. 1.961 Pegawai Depkeu Mendapat Sanksi.Diakses tanggal 14 Mei 2012 dari<http://aparaturnegara.bappenas.go.id/?p=439>

Keban, Yeremias T. 2008. Enam Dimensi Strategis Administrasi Publik : Konsep, Teori, dan Isu. Edisi 2. Yogyakarta: Gava Media.

Kompas, 12 Januari 2007. 55 Persen PNS Berkinerja Buruk.

Miles, Matthew B, Michael. A. Huberman. 1992. Analisis Data Kualitatif. Bandung: PT Remaja Rosdakarya.

Moekijat. 1987. Manajemen Kepegawaian.Bandung: Alumni. , 1991.Administrasi Kepegawaian Negara. Bandung: Mandar Maju.

Moenir, HAS. 2001. Manajemen Umum di Indonesia. Jakarta: Bumu Aksara.

Nugroho, Riant. 2009. Public Policy. Jakarta: PT. Elex Media Komputindo Kelompok Gramedia. 


\section{REFORMASI}

ISSN 2088-7469 (Paper) ISSN 2407-6864 (Online)

Volume 9 Nomor 1 (2019)

Siagian, Sondang P. 2010. Manajemen Sumber Daya Manusia. Jakarta: Bumi Aksara.

Soenarko SD. 2000. Public Policy: Pengertian Pokok Untuk Memahami Dan Analisa Kebijaksanaan Pemerintah. Surabaya: Airlangga University.

Sulistiyani, Ambar Teguh, 2004. Memahami Good Governance Dalam Perspektif Sumber Daya Manusia. Yogyakarta: Gaya Media. 